\title{
Anti-Tumor Efficacy of a Novel Antisense Anti-MDM2 Mixed-Backbone Oligonucleotide in Human Colon Cancer Models: p53-Dependent and p53-Independent Mechanisms
}

\author{
Hui Wang, ${ }^{1,3}$ Li Nan, ${ }^{1}$ Dong Yu, ${ }^{5}$ J. Russell Lindsey, ${ }^{2,3}$ Sudhir Agrawal, ${ }^{5}$ and Ruiwen Zhang ${ }^{1,3,4}$ \\ ${ }^{1}$ Department of Pharmacology and Toxicology, Division of Clinical Pharmacology, University of Alabama \\ at Birmingham, Birmingham, Alabama, USA \\ ${ }^{2}$ Department of Genomics and Pathobiology, University of Alabama at Birmingham, Birmingham, \\ Alabama, USA \\ ${ }^{3}$ Comprehensive Cancer Center, University of Alabama at Birmingham, Birmingham, Alabama, USA \\ ${ }^{4}$ Gene Therapy Center, University of Alabama at Birmingham, Birmingham, Alabama, USA \\ ${ }^{5}$ Hybridon, Inc., Cambridge, Massachusetts, USA \\ Accepted March 19, 2002
}

\begin{abstract}
Background: The MDM2 oncogene is amplified or overexpressed in many human cancers and MDM2 levels are associated with poor prognosis. MDM2 not only serves as a negative regulator of $\mathrm{p} 53$ but also has p53-independent activities. This study investigates the functions of the MDM2 oncogene in colon cancer growth and the potential value of MDM2 as a drug target for cancer therapy, by inhibiting MDM2 expression with an antisense antihuman-MDM2 oligonucleotide.

Materials and Methods: The selected antisense mixedbackbone oligonucleotide was evaluated for its in vitro and in vivo antitumor activity in human colon cancer models: LS174T cell line containing wild-type p53 and DLD-1 cell line containing mutant p53. The levels of MDM2, p53 and p21 proteins were quantified by Western blot analysis.
\end{abstract}

Results: In vitro antitumor activity was found in both cell lines, resulting from specific inhibition of MDM2 expression. In vivo antitumor activity of the oligonucleotide occurred in a dose-dependent manner in both models and synergistically or additive therapeutic effects of MDM2 inhibition and the cancer chemotherapeutic agents 10-hydroxycamptothecin and 5-fluorouracil were also observed.

Conclusions: These results suggest that MDM2 have a role in tumor growth through both p53-dependent and p53independent mechanisms. We speculate that MDM2 inhibitors have a broad spectrum of antitumor activities in human cancers regardless of p53 status. This study should provide a basis for future development of anti-MDM2 antisense oligonucleotides as cancer therapeutic agents used alone or in combination with conventional chemotherapeutics.

\section{Introduction}

Human cancer has been increasingly viewed as diseases characterized by loss of cell-cycle control and increased genetic instability. Both oncogenes and tumor suppressor genes play a crucial role in cancer formation, growth, and progression. Activation of protooncogenes that promote cell growth in combination with the inactivation of tumor suppressor genes that inhibit cell growth by means of cell growth arrest and induction of programmed cell death or apoptosis leads to tumor progression and malignancy. Perhaps the most important and best-studied tumor suppressor gene is p53 (1). Abnormalities of the p53 tumor

Correspondence and reprint requests should be addressed to: Ruiwen Zhang, MD, PhD, DABT, Department of Pharmacology and Toxicology, University of Alabama at Birmingham, VH 113, Box 600, 1670 University Boulevard, Birmingham, AL 35294-0019. Phone: 205-934-8558; fax: 205-975-9330; e-mail: ruiwen.zhang@ccc.uab.edu. suppressor gene are among the most frequent molecular defects in human and animal neoplasia. Nevertheless, studies also have provided increasing evidence that the tumor suppressor function of $\mathrm{p} 53$ can be inhibited without mutation. Perhaps one of the most important findings in this area is that the MDM2 oncogene is a negative regulator of wildtype p53 $(2,3)$. The MDM2-p53 autoregulatory feedback loop regulates the intracellular p53 function: the MDM2 gene is a target for direct transcriptional activation of p53 and MDM2 protein is a negative regulator of p53 (3-8). In addition, MDM2 protein interacts with other cellular proteins that are involved in cell-cycle regulation, including pRb, E2F1/DP1, p300, and p19ARF (3-8). Overexpression of MDM2 is demonstrated in a variety of human tumors and may be due to gene amplification (9), increased transcription $(10,11)$, and/or enhanced translation $(12,13)$. Many studies have shown that overexpression of MDM2 is associated with poor prognosis in 
many human malignancies (9-31). Therefore, MDM2 plays a crucial role in cell-cycle control and tumor transformation and growth. Like p53, MDM2 has been suggested as a target for rational drug design for cancer therapy $(6-8,32-39)$.

Gastrointestinal cancers remain a major public health problem both in the United States and worldwide (40). In the United States, colorectal cancer is the second most common cancer in women and the third most common cancer in men (40). Although there has been considerable progress in research on the etiology, prevention, and experimental therapy of gastrointestinal cancers, no fully effective approaches are available currently for the treatment and prevention of this disease. MDM2 overexpression has been observed in human colorectal cancer (25). The objective of the present study was to use both in vitro and in vivo models to evaluate the therapeutic effectiveness of a recently identified anti-human-MDM2 antisense oligonucleotide $(38,39)$ in the treatment of human colorectal cancers when administered alone or in combination with conventional chemotherapeutic agents.

\section{Materials and Methods}

\section{Test Oligonucleotides}

The test oligonucleotide, Oligo AS, a 20-mer mixedbackbone oligonucleotide (5'UGACACCTGTTCTCACUCAC-3') and its mismatched control (Oligo ASM, 5'UGTCACCCTTTTTCATUCAC-3') were synthesized, purified, and analyzed as previously described (41). Two nucleosides at the 5 'end and four nucleosides at the $3^{\prime}$ end are $2^{\prime} \mathrm{O}$ - methylribonucleosides (represented by boldface letters); the remaining are deoxynucleosides. The underlined nucleosides of Oligo ASM are the sites of the mismatched controls compared with Oligo AS. For both mixed-backbone oligonucleotides, all internucleotide linkages are phosphorothioate. The purity of the oligonucleotides was shown to be greater than $90 \%$ by capillary gel electrophoresis and PAGE, with the remainder being $\mathrm{n}-1$ and $\mathrm{n}-2$ products. The integrity of the internucleotide linkages was confirmed by ${ }^{31} \mathrm{P}-\mathrm{NMR}$.

\section{Chemicals and Reagents}

Cell culture media, anti-human $\beta$-actin (SC-15) monoclonal antibody, and phosphate-buffered saline (PBS) were obtained from Sigma Chemical Co. (St. Louis, MO, USA). Fetal bovine serum (FBS), antibodies against p53 and p21, lipofectin, trypsin, penicillin-streptomycin, and trypan blue stain were purchased from GIBCO-BRL (Grand Island, NY, USA). The anti-human-MDM2 monoclonal antibody $(37,38)$ was kindly provided by J. Chen (Moffitt Cancer Center, Tampa, FL, USA). Chemotherapeutic agents adriamycin and 5-fluorouracil (5-FU) were obtained from Sigma. The natural product topoisomerase I inhibitor 10-hydroxycamptothecin (HCPT) was obtained from the Midwest Co. (Beijing,
China) with the purity of the drug being greater than $98 \%(42)$.

\section{Cell Culture}

The tumor cell lines, LS174T and DLD-1, were obtained from the American Type Culture Collection (Rockville, MD, USA) and cultured according to their instructions. LS174T cells were cultured in MEM with $0.1 \mathrm{mM}$ nonessential amino acids and Earle's balanced salt solution containing 10\% FBS and DLD-1 cells in RPMI 1640 medium containing $10 \%$ FBS. All media included $1 \%$ penicillin/streptomycin. The in vitro biological activity of oligonucleotides was determined by using the conditions described earlier $(37-39,43)$. Cells were incubated with Oligos AS or ASM at various concentrations for $72 \mathrm{hr}$, in the presence of lipofectin $(7 \mu \mathrm{g} / \mathrm{ml})$. The effects on cell growth were analyzed by trypan blue viability staining (43).

\section{Animal Tumor Model}

Human cancer xenograft models were established using the methods reported previously $(39,43,44)$. Pathogen-free female nude mice ( 5 weeks old) were purchased from Frederick Cancer Research and Development Center (Frederick, MD, USA) and accommodated for 5 days for environmental adjustment prior to study. Cultured LS174T or DLD-1 cells were harvested from the monolayer cultures, washed twice with culture medium (without FBS), resuspended in FBS-free culture medium, and injected subcutaneously $\left(2 \times 10^{6}\right.$ cells, total volume $\left.0.2 \mathrm{ml}\right)$ into the left inguinal area of the mice. The animals were monitored by general clinical observation, determination of body weight, and measurement of tumor growth.

\section{In Vivo Chemotherapy}

The animals bearing human cancer xenografts were randomly divided into various treatment groups and a control group (6 mice/group). The control (nonoligo-treated) group received physiologic saline only. The oligonucleotides dissolved in physiological saline $(0.9 \% \mathrm{NaCl})$ were administered by intraperitoneal injection at various dose levels. The injection volume was based on the body weight $(5 \mu \mathrm{l} / \mathrm{g}$ body weight) and the oligonucleotide concentrations were adjusted on the basis of the dose. HCPT was suspended in cottonseed oil and given by gavage (volume; $10 \mu \mathrm{l} / \mathrm{g}$ body weight). The dose was $3 \mathrm{mg} / \mathrm{kg} /$ day, 7 consecutive days for the first week of treatment and every other day afterwards. 5-FU was given by intraperitoneally at a dose of $10 \mathrm{mg} / \mathrm{kg} /$ day (volume; $5 \mu \mathrm{l} / \mathrm{g}$ body weight). Tumor growth was monitored by the measurement, with calipers, of two perpendicular diameters of the implant every other day. Tumor weight (g) was calculated by the formula

$$
1 / 2 a \times b^{2}
$$


where $a$ is the long diameter $(\mathrm{cm})$ and $b$ is the short diameter $(\mathrm{cm})$. Tumor xenograft pathology was evaluated by using the methods previously reported (43).

Western Blot Analysis

The MDM2, p53, and p21 levels in cultured cells or tumor xenografts were analyzed by using the methods described previously (37-39). In brief, cell lysates or tumor tissue homogenates containing identical amounts of total protein were fractionated by SDS-PAGE and transferred to Bio-Rad Trans-Blot nitrocellulose membranes (Bio-Rad Laboratories, Hercules, CA, USA). The nitrocellulose membrane was then incubated with blocking buffer (PBS containing $0.1 \%$ Tween 20 and $5 \%$ nonfat milk) for $1 \mathrm{hr}$ at room temperature and washed with the washing buffer (PBS containing $0.1 \%$ Tween 20) for $5 \mathrm{~min}$ twice. The membrane was incubated with primary (anti-MDM2, anti-p53, anti-p21, or anti- $\beta$-actin) antibody overnight at $4^{\circ} \mathrm{C}$ or for $1 \mathrm{hr}$ at room temperature with gentle shaking. The membrane was washed with the washing buffer for $15 \mathrm{~min}$ and then twice for $5 \mathrm{~min}$, and then incubated with 1:5000 diluted goat anti-mouse IgG-horse radish peroxidase conjugated antibody (Bio-Rad) for $\mathrm{l} \mathrm{hr}$ at room temperature. After washing as described, the protein of interest was detected by ECL reagents from Amersham (Arlington Height, IL, USA). The density of each protein band was analyzed by a densitometry measurement (Bio-Rad Model GS-670 Imaging Densitometer) and expressed as percentage of the controls, normalized by corresponding $\beta$-actin level.

\section{Results}

Antitumor Activity of Antisense Anti-MDM2 Oligo AS in Human Colon Cancer LS174T Model That Contains Wild-Type $p 53$

In Vitro Biological Activity In vitro inhibition of MDM2 expression by Oligo AS was shown in a sequence-specific, dose-dependent manner (Fig. 1A). The anti-MDM2 oligo, Oligo AS, specifically inhibited MDM2 expression in LS 174T cells, and p53 and p21 levels were elevated accordingly. The mismatched control oligonucleotide, Oligo ASM, had minimal effects on MDM2, p53, or p21 protein levels at various concentrations up to $1000 \mathrm{nM}$, the highest concentration tested in the study. Oligo AS inhibited the growth of tumor cell lines in vitro in a dose-dependent manner, with an $I C_{50}$ value of 323 $\mathrm{nM}$ for a 72-hr treatment. The mismatched oligonucleotide, Oligo ASM, had no significant effect on tumor cell growth.

Following in vitro exposure to combinations of oligos and the chemotherapeutic agents, HCPT, adriamycin, and 5-FU, the protein levels of MDM2, p53, and p21 were determined in LS174T cells (Fig. 2). Cells were incubated with $400 \mathrm{nM}$ of Oligo in the presence of lipofectin for $24 \mathrm{hr}$,
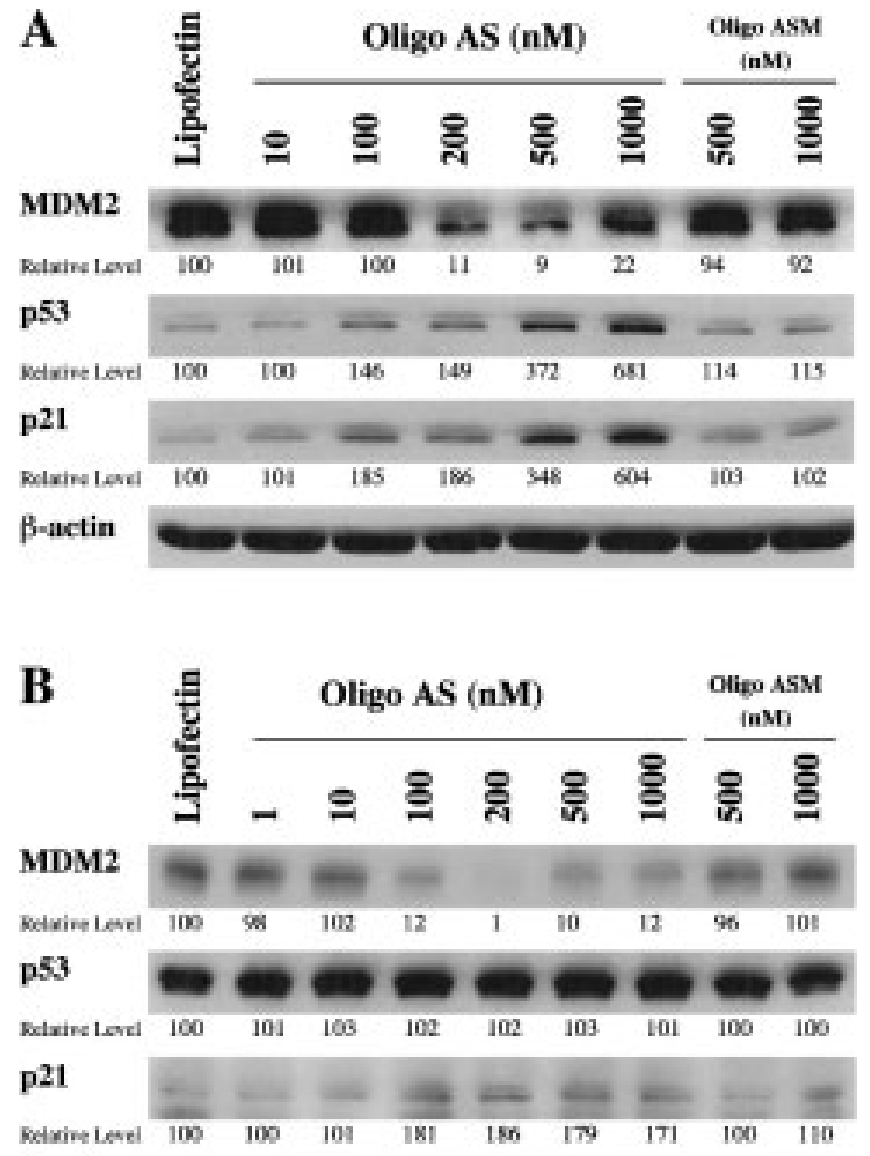

B-actin

Fig. 1. Effects of anti-MDM2 antisense oligonucleotides on MDM2, p53, and p21 protein levels in LS174T (A) and DLD-1 (B) cells in culture. Cells were incubated with Oligo AS at various concentrations for $24 \mathrm{hr}$, in the presence of lipofectin $(7 \mu \mathrm{g} / \mathrm{ml})$. Identical total protein $(20 \mu \mathrm{g})$ was analyzed by SDS-PAGE, followed by Western blotting. Inhibitory effects of Oligo AS on MDM2 expression are shown in a dose-dependent manner, with greater than $90 \%$ inhibition be observed at

$500 \mathrm{nM}$ of Oligo AS. The protein levels of p53 and/or p2 1 were increased in a dose-dependent manner. The control mismatched Oligo ASM had minimal effects on the levels of these proteins. Relative levels of each protein were expressed as percentage of control, normalized by corresponding $\beta$-actin level.

followed by addition of various concentrations of chemotherapeutic agents and incubation for additional $24 \mathrm{hr}$. As illustrated in Figure 2 (panel I, lanes A), HCPT induced p53, p21, and MDM2 in a dose-dependent manner, as we reported in an earlier study with human breast cancer cell line MCF-7 (45). Following the treatment with Oligo AS, MDM2 expression was inhibited, resulting in significantly elevated p53 and p21 levels (panel I, lanes B). The mismatched control Oligo ASM showed minimal effect on the protein levels of MDM2, p53, or p2 1 (panel I, lanes C). Adriamycin slightly induced p53 and p21 in LS174T cells (panel II, lanes A). Following the combination treatment with Oligo AS, MDM2 expression was 


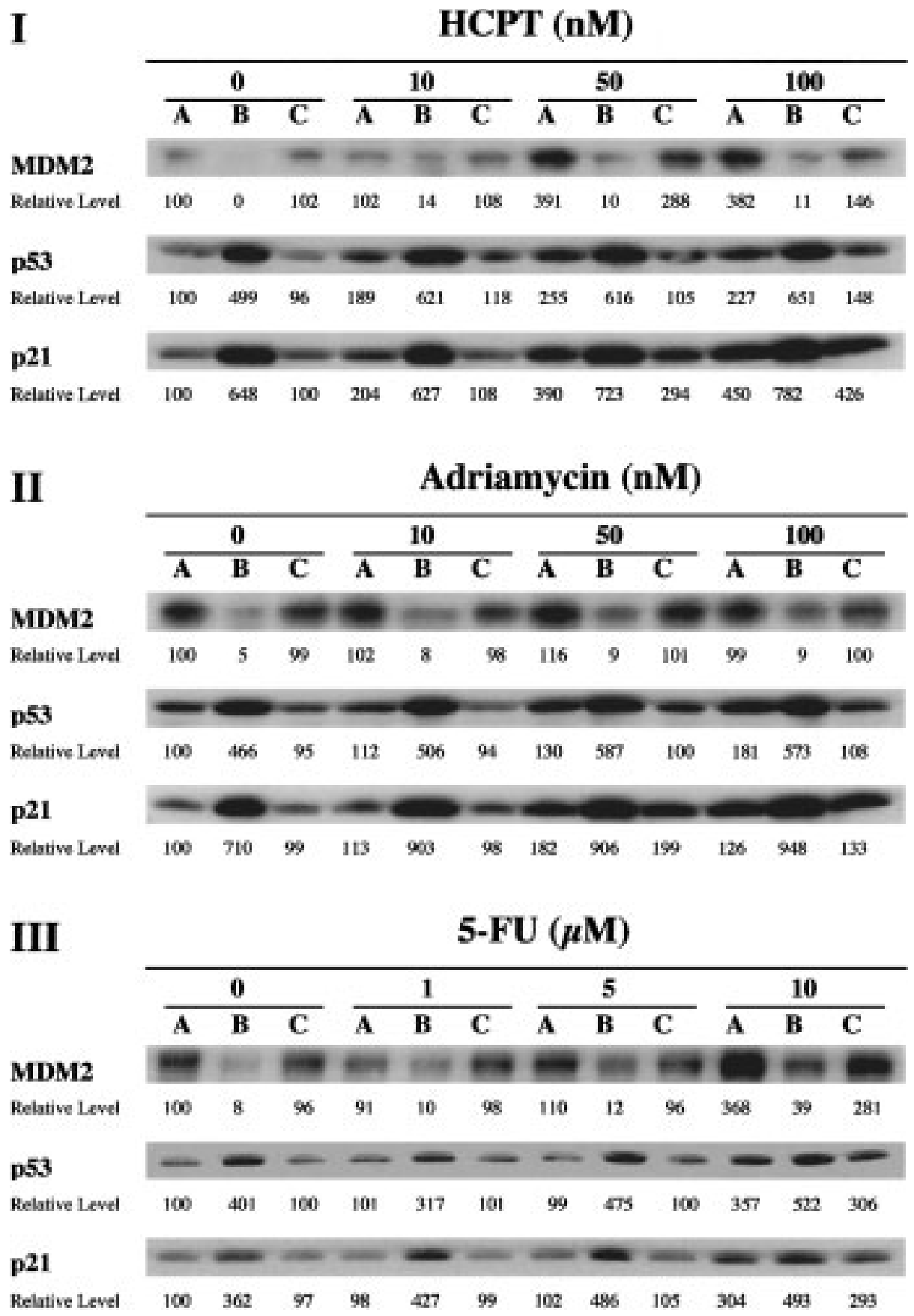

Fig. 2. Synergistic effects of combination treatment of anti-MDM2 oligo AS and the cancer chemotherapeutic agents on MDM2, p53, and p21 protein levels in LS174T cells in culture. Cells were incubated with $400 \mathrm{nM}$ Oligo AS or ASM in the presence of lipofectin for $24 \mathrm{hr}$, followed by addition of various concentrations of HCPT (panel I), adriamycin (panel II), or 5-FU (panel III) and incubation for additional $24 \mathrm{hr}$. At various concentrations, the effects on MDM2, p53, and p21 levels were evaluated following treatment with cytotoxic agents alone (lanes A) or pre-treatment with Oligo AS (lanes B) or Oligo ASM (lanes C). Relative levels of each protein were expressed as percentage of control (lipofectin alone), normalized by corresponding $\beta$-actin level.

inhibited, resulting in significantly elevated p53 and p2 1 levels (panel II, lanes B). The mismatched control Oligo ASM showed minimal effect on the protein levels of MDM2, p53, or p21 (panel II, lanes C). The effects of Oligo AS on 5-FU-induced p53, p21, and MDM2 levels were also evaluated (Fig. 2, panel III). 5-FU induced p53, p21, and MDM2 in a dose- dependent manner (panel III, lanes A). Following the treatment with Oligo AS, MDM2 expression was inhibited, resulting in significantly elevated p53 and p2l levels (panel III, lanes B). The mismatched control Oligo ASM showed minimal effect on the protein levels of MDM2, p53, or p21 (panel III, lanes C). 
In Vivo Biological Activity

Antitumor Activity Based on previous studies with cell lines that contain wild-type p53 (39), the effect of Oligo AS on in vivo tumor growth was first evaluated in LS174T xenograft model at a daily intraperitoneal dose of $20 \mathrm{mg} / \mathrm{kg}$. Oligo AS showed significant inhibitory effect on tumor growth (Fig. 3 and Table 1). The mismatched control Oligo ASM showed minimal effect (Fig. 3A and Table 1). Following HCPT treatment $(3 \mathrm{mg} / \mathrm{kg} /$ day for the first week and $3 \mathrm{mg} / \mathrm{kg}$ every other day for remaining
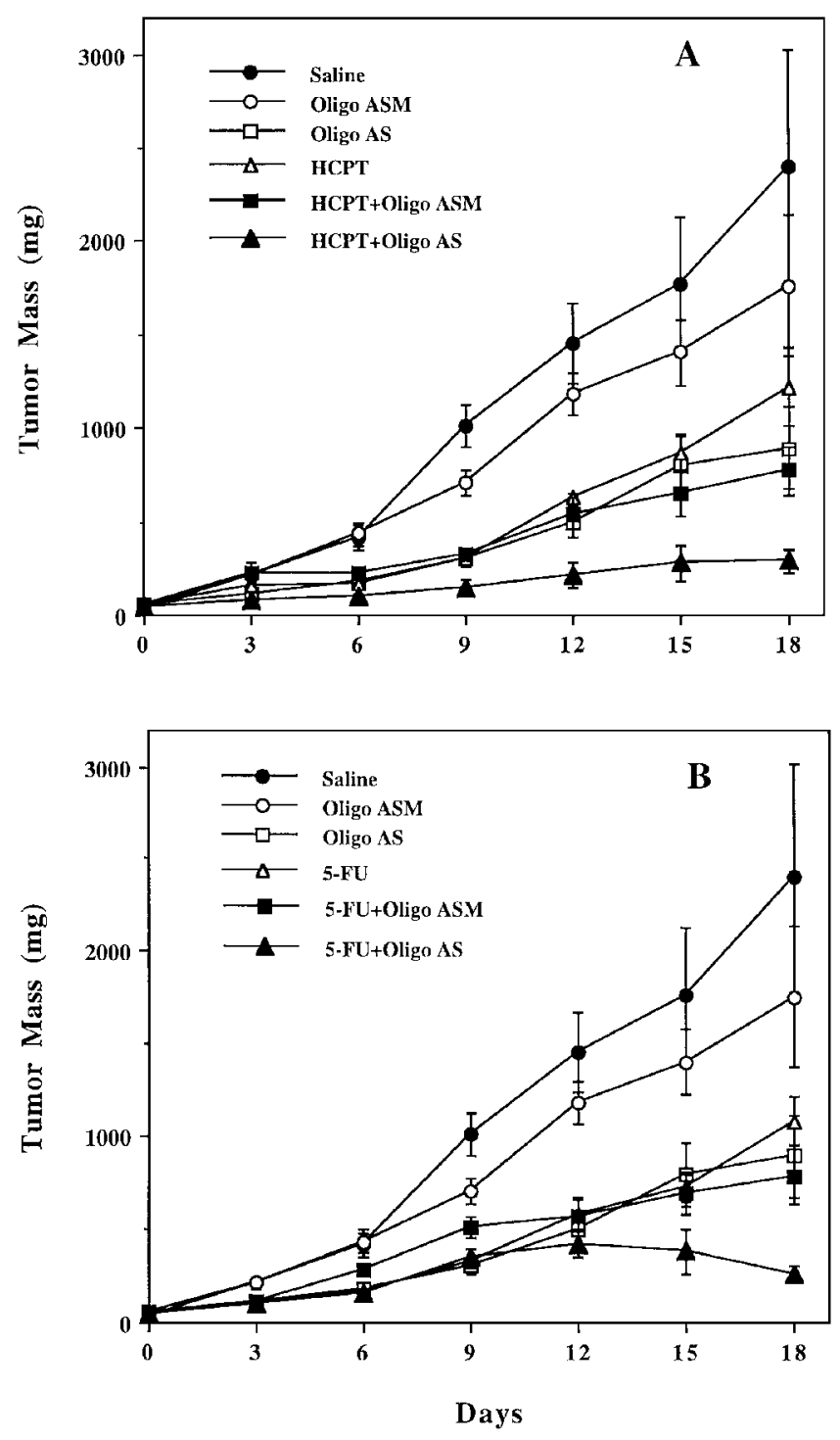

Fig. 3. In vivo synergistic effects between Anti-MDM2 oligonucleotide, Oligo AS, and chemotherapeutic agents HCPT and 5-FU in mice bearing human colon cancer LS174T xenografts. Doses for drugs alone or in combinations are Oligo AS and ASM, $20 \mathrm{mg} / \mathrm{kg} /$ day; HCPT, $3 \mathrm{mg} / \mathrm{kg} /$ day for the first week and $3 \mathrm{mg} / \mathrm{kg}$ every other day for remaining treatment period; and $5-\mathrm{FU}, 10 \mathrm{mg} / \mathrm{kg} /$ day. The therapeutic effects for each treatment are listed in Table 1 . The host toxicity (survival rate) is listed in Table 2. Synergistic or additive effects on tumor growth were noted in combination therapy. treatment period), tumor growth was inhibited by approximately $50 \%$ (Fig. 3A and Table 1). Following the combination treatment of Oligo AS and HCPT, significant synergistic effects were observed (Fig. 3A and Table 1). At the end of the experiment, the mean tumor size of the animals treated with HCPT and Oligo AS was $12 \%$ of that of the control animals treated with saline, whereas the mean tumor sizes for animals treated with Oligo AS or HCPT alone were $37.3 \%$ and $50.8 \%$ of that of the controls, respectively (Table 1). Similar significantly synergistic effects were observed following the combination treatment of Oligo AS and 5-FU (Fig. 3B and Table 1). At the end of the experiment, the mean tumor size of the animals treated with 5-FU and Oligo AS was $10.9 \%$ of that of the control animals treated with saline, whereas the mean tumor sizes for animals treated with Oligo AS or HCPT alone were $37.3 \%$ and $45.3 \%$ of that of the controls, respectively (Table 1 ). The mismatched control Oligo ASM showed no significant effect on HCPT or 5-FU-associated tumor growth inhibition (Fig. 3 and Table 1).

Xenograft Pathology Tumors from control mice and mice given Oligo ASM were indistinguishable histologically. Cellularity of the tumors was typical of anaplastic colon cancer as evidenced by disorderly gland formation, oval to round open-faced nuclei, some degree of polarity of cells with apical clear zones and basilar nuclei, modest to abundant mucous production, and numerous mitotic figures. Tumor tissues from mice treated with Oligo AS contained patches of collagenous connective tissues replacing tumor and necropurulent, ulcerative changes. No significant histologic changes were found in tumors of mice treated with 5-FU alone. Tissues from mice treated with combination of 5-FU and Oligo AS were small nodules of scar tissue containing scattered islands of tumor cells. Tumor tissues from mice treated with HCPT alone or in combination with Oligo ASM contained large areas of necropurulent degeneration with ulceration of adjacent skin. Tumor tissues from mice treated with HCPT in combination with Oligo AS were characterized by marked tumor atrophy.

In Vivo Inhibition of MDM2 Expression and Activation of $p 53$ Western blot analyses of pooled LS174T xenograft tissues indicated that Oligo AS specifically inhibited MDM2 expression and activated p53 in vivo (Fig. 4A). The control Oligo ASM had no effect on the protein levels, further demonstrating the specificity of Oligo AS.

Host Toxicity One of the concerns of combination therapy is the potential risk of increased host toxicity. In the present study, no significant increase in host toxicity, in terms of body weight gain/loss or survival rates, was observed with combination treatment (Table 2). 
Table 1. Therapeutic effectiveness of Anti-MDM2 oligonucleotide administered alone or in combination with cytotoxic agents in animals bearing LS174T xenografts

\begin{tabular}{|c|c|c|c|c|c|c|}
\hline \multirow[b]{2}{*}{ Day } & & \multirow{2}{*}{$\begin{array}{c}\text { No Oligo } \\
{[1]} \\
(\% \mathrm{~T}: \mathrm{C})\end{array}$} & \multicolumn{2}{|c|}{$+\mathbf{A S M}$} & \multicolumn{2}{|c|}{+ Anti-MDM2 AS } \\
\hline & & & $\begin{array}{c}{[2]} \\
(\% \mathrm{~T}: \mathrm{C})\end{array}$ & $\begin{array}{c}\text { Ratio (\%) } \\
([2] /[1])\end{array}$ & $\begin{array}{c}{[3]} \\
(\% \mathrm{~T}: \mathrm{C})\end{array}$ & $\begin{array}{c}\text { Ratio (\%) } \\
([3]) /[1])\end{array}$ \\
\hline 3 & $\begin{array}{l}\text { Oligo alone } \\
\text { HCPT } \\
5-F U\end{array}$ & $\begin{array}{r}100 \\
74 \\
50\end{array}$ & $\begin{array}{r}99 \\
103 \\
51\end{array}$ & $\begin{array}{r}99 \\
138 \\
102\end{array}$ & $\begin{array}{l}51 \\
37 \\
47\end{array}$ & $\begin{array}{l}51 \\
49 \\
94\end{array}$ \\
\hline 6 & $\begin{array}{l}\text { Oligo alone } \\
\text { HCPT } \\
5-F U\end{array}$ & $\begin{array}{r}100 \\
41 \\
40\end{array}$ & $\begin{array}{r}105 \\
55 \\
67\end{array}$ & $\begin{array}{l}105 \\
134 \\
167\end{array}$ & $\begin{array}{l}44 \\
24 \\
38\end{array}$ & $\begin{array}{l}44 \\
58 \\
96\end{array}$ \\
\hline 9 & $\begin{array}{l}\text { Oligo alone } \\
\text { HCPT } \\
5-F U\end{array}$ & $\begin{array}{r}100 \\
30 \\
33\end{array}$ & $\begin{array}{l}70 \\
32 \\
51\end{array}$ & $\begin{array}{r}70 \\
107 \\
156\end{array}$ & $\begin{array}{l}30 \\
15 \\
35\end{array}$ & $\begin{array}{r}30 \\
50 \\
108\end{array}$ \\
\hline 12 & $\begin{array}{l}\text { Oligo alone } \\
\text { HCPT } \\
5-\mathrm{FU}\end{array}$ & $\begin{array}{r}100 \\
44 \\
40\end{array}$ & $\begin{array}{l}82 \\
37 \\
39\end{array}$ & $\begin{array}{l}82 \\
85 \\
99\end{array}$ & $\begin{array}{l}34 \\
15 \\
29\end{array}$ & $\begin{array}{l}34 \\
34 \\
73\end{array}$ \\
\hline 15 & $\begin{array}{l}\text { Oligo alone } \\
\text { HCPT } \\
5-F U\end{array}$ & $\begin{array}{r}100 \\
49 \\
41\end{array}$ & $\begin{array}{l}79 \\
37 \\
39\end{array}$ & $\begin{array}{l}79 \\
75 \\
95\end{array}$ & $\begin{array}{l}45 \\
16 \\
22\end{array}$ & $\begin{array}{l}45 \\
32 \\
53\end{array}$ \\
\hline 18 & $\begin{array}{l}\text { Oligo alone } \\
\text { HCPT } \\
5 \text {-FU }\end{array}$ & $\begin{array}{r}100 \\
51 \\
45\end{array}$ & $\begin{array}{l}73 \\
32 \\
33\end{array}$ & $\begin{array}{l}73 \\
63 \\
72\end{array}$ & $\begin{array}{l}37 \\
12 \\
11\end{array}$ & $\begin{array}{l}37 \\
24 \\
24\end{array}$ \\
\hline
\end{tabular}

The ratio $([2]) /[1]$ or [3]/[1]) can be used to illustrate the potential additive or synergistic effects when the oligos were given in combination with cytotoxic agents. When the ratio for combination therapy is less thatn $100 \%$ (compared to cytotoxic agents alone), an effect of antisense oligo is indicated. If the ratio for combination therapy is the same as that of oligo treatment alone, an additive effect is indicated. If the ratio for combination therapy is significantly less than that of oligo treatment alone, a synergistic effect is indicated. For example, at the end of the experiment (day 18), the ratio for $5-\mathrm{FU}+\mathrm{AS} / 5-\mathrm{FU}$ is $24 \%(10.9 \% / 45 \%)$ and less than $100 \%$, indicating an effect of oligo AS, and, in addition, this ratio is less than the ratio for oligo AS alone (37\%; AS/Saline), indicating a synergistic effect between 5-FU and Oligo AS. The ratio for 5-FU + ASM/5-FU is $72 \%(33 \% / 45 \%)$ and less than $100 \%$, indicating an effect of oligo ASM; however, this ratio is almost the same as the ratio for oligo ASM alone (73\%), indicating no synergistic effect, but an additive effect, between 5-FU and Oligo ASM. In conclusion, additive or synergistic effects between HCPT and Oligo AS were found throughout the treatment period. Additive or synergistic effects between 5-FU and Oligo AS were found only on days 15 and 18 . No additive or synergistic effects between Oligo ASM and HCPT or 5-FU were found, except for HCPT + ASM on days 15 and 18 and 5-FU + ASM on day 18. An additive effect between HCPT and ASM was found on these days.

Dose-Dependent Effects of Oligo AS on Chemotherapeutic Effects of HCPT To confirm the above results, in vivo synergistic effects between HCPT and Oligo AS were further determined in LS174T model, in a separate study using three different doses of Oligo AS (1, 10, $20 \mathrm{mg} / \mathrm{kg} /$ day, 5 days/week for 2 weeks). As illustrated in Figure 5A, at the $1 \mathrm{mg} / \mathrm{kg}$ level, Oligo AS showed no effect on HCPT therapeutic efficacy. At the 10 and $20 \mathrm{mg} / \mathrm{kg}$ levels, Oligo AS significantly increased HCPT efficacy.

\section{Antitumor Activity of Antisense Anti-MDM2 Oligo AS in Human Colon Cancer DLD-1 Model That Contains Mutant $p 53$}

In Vitro Biological Activity In vitro inhibition of MDM2 expression by Oligo AS occurred in a sequence-specific, dose-dependent manner (Fig. 1B). The best inhibitory effect $(>95 \%)$ on MDM2 expression in DLD-1 cells was observed with $200 \mathrm{nM}$ Oligo AS in the presence of lipofectin, whereas the inhibitory effects were approximately $90 \%$ at higher concentrations (500 and $1000 \mathrm{nM})$. No significant changes in the protein levels of the mutant p53 were observed after Oligo AS treatment. The p21 levels were elevated at the concentration of $100 \mathrm{nM}$ or higher, which is independent of p53. Control oligonucleotide, Oligo ASM, had no effect on MDM2, p53, or p21 protein levels following treatment of the cells with various concentrations of ASM up to 1000 nM. Oligo AS inhibited the growth of tumor cell lines in vitro in a dose-dependent manner, with an $I C_{50}$ value of $140 \mathrm{nM}$ for a 72 -hr treatment. The mismatched oligonucleotide, Oligo ASM, had no significant effect on tumor cell growth.

The protein levels of MDM2, p53, and p21 were determined in DLD- 1 cells following in vitro combination treatment with Oligos $(200 \mathrm{nM})$ and 


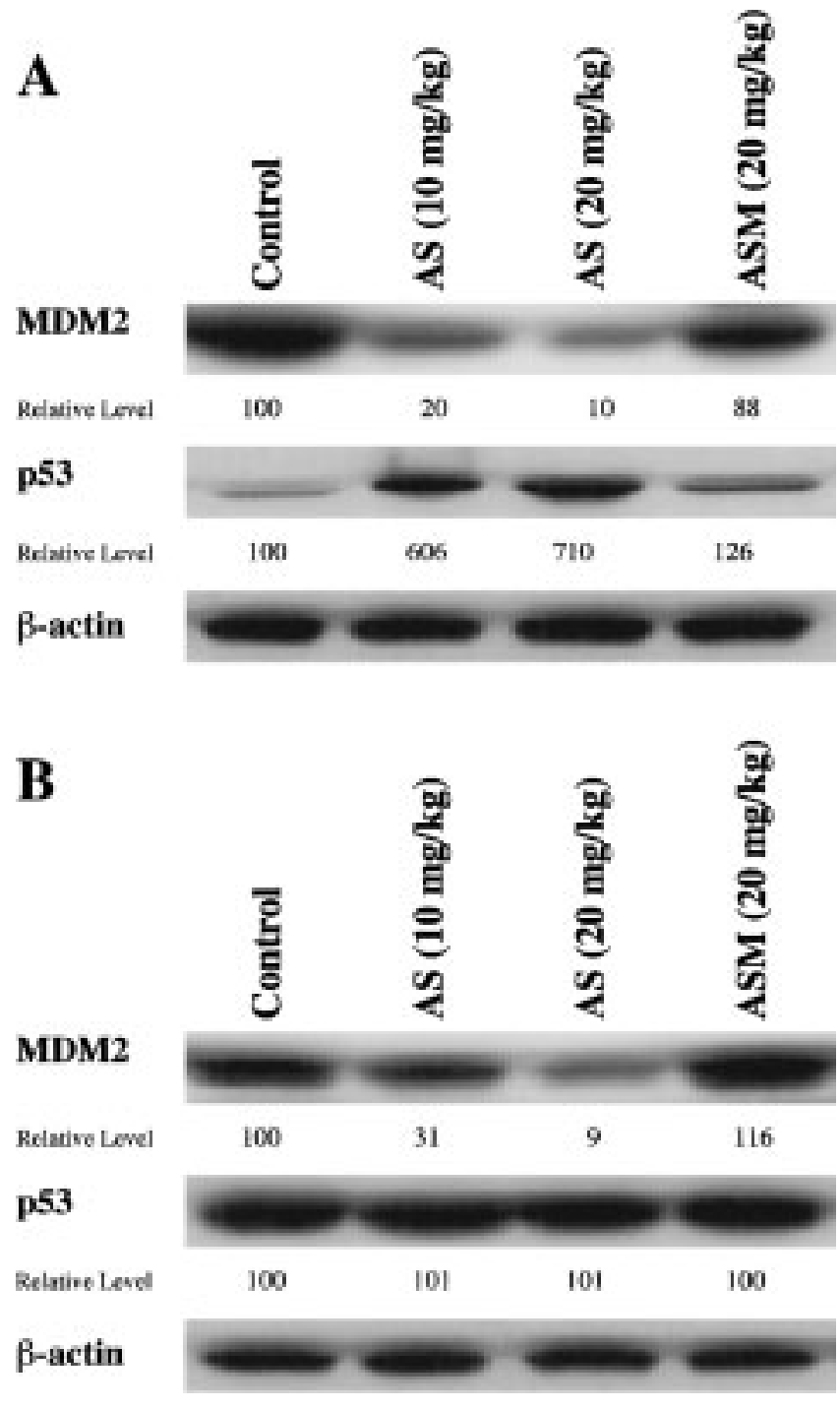

Fig. 4. In vivo inhibition of MDM2 expression by Oligos. Oligo AS inhibited the MDM2 expression in LS174T xenograft (A) and DLD-1 xenograft (B). Identical amounts of total protein from the tumor homogenates $(100 \mu \mathrm{g})$ were analyzed by Western blot using a monoclonal anti-MDM2 or anti-p53 antibody. The mismatch oligonucleotide, Oligo ASM, showed no effect. The p53 levels were elevated in LS174T model and no change in p53 levels was observed in DLD-1 model. Relative levels of each protein were expressed as percentage of control (saline), normalized by corresponding $\beta$-actin level.

the chemotherapeutic agents, HCPT, adriamycin, and 5-FU (Fig. 6). Cells were incubated with 200 $\mathrm{nM}$ Oligo in the presence of lipofectin for $24 \mathrm{hr}$, followed by addition of various concentrations of chemotherapeutic agents and incubation for additional 24 hr. As illustrated in Figure 6 (panel I, lanes A), HCPT slightly induced MDM2 but increased p21 levels in a dose-dependent manner as we reported in an earlier study with human breast cancer cell line MDA-MB-468, which contains mutant p53 (45). Following the treatment with Oligo AS, MDM2 expression was inhibited, resulting in
Table 2. Survival rates of animals bearing LS174T xenografts and treated with anti-MDM2 oligonucleotide administered alone or in combination with cytotoxic agents

\begin{tabular}{llccc}
\hline $\begin{array}{l}\text { Day } \\
\text { AS }\end{array}$ & & $\begin{array}{c}\text { No Oligo } \\
(\%)\end{array}$ & $\begin{array}{c}\text { +ASM } \\
(\%)\end{array}$ & $\begin{array}{c}\text { Anti-MDM2 } \\
(\%)\end{array}$ \\
\hline 3 & Oligo alone & 100 & 100 & 100 \\
& HCPT & 100 & 100 & 100 \\
& 5-FU & 100 & 100 & 100 \\
6 & Oligo alone & 100 & 100 & 100 \\
& HCPT & 100 & 100 & 100 \\
& 5-FU & 100 & 100 & 100 \\
9 & Oligo alone & 100 & 100 & 100 \\
& HCPT & 67 & 83 & 83 \\
& 5-FU & 100 & 100 & 83 \\
12 & Oligo alone & 100 & 100 & 100 \\
& HCPT & 50 & 83 & 83 \\
& 5-FU & 100 & 100 & 83 \\
15 & Oligo alone & 100 & 100 & 100 \\
& HCPT & 50 & 67 & 83 \\
& 5-FU & 100 & 100 & 83 \\
18 & Oligo alone & 100 & 100 & 100 \\
& HCPT & 50 & 67 & 67 \\
& 5-FU & 100 & 100 & 83 \\
& & & & \\
\hline \multirow{4}{*}{100} & & &
\end{tabular}

significantly elevated p21 levels (panel I, lanes B). The mismatched control Oligo ASM showed minimal effects on the protein levels of MDM2 and p21 (panel I, lanes C). No changes in p53 levels were observed in cells untreated or treated with HCPT in presence of lipofectin, Oligo AS or ASM, indicating that the changes in MDM2 and p2l levels were independent of $\mathrm{p} 53$.

Also shown in Figure 6, adriamycin slightly induced p21 in DLD-1 cells (panel II, lanes A). Following the treatment with Oligo AS, MDM2 expression was inhibited, resulting in significantly elevated p21 levels (panel II, lanes B). The mismatched control Oligo ASM showed minimal effects on the protein levels of MDM2 and p21 (panel II, lanes C). No changes in p53 levels were observed in cells untreated or treated with adriamycin, Oligo AS or ASM, further indicating that the changes in MDM2 and p21 levels were independent of p53. 5-FU-induced MDM2 (panel III, lanes A). Following the combination treatment with Oligo AS, MDM2 expression was inhibited, but no changes in p2 I levels were observed (panel III, lanes B). The mismatched control Oligo ASM showed minimal effects on the protein levels of MDM2, p53 or p21 (panel III, lanes C).

In Vivo Biological Activity The effect of Oligo AS on in vivo tumor growth was evaluated in the DLD1 xenograft model at various daily intraperitoneal doses (1, 10, and $20 \mathrm{mg} / \mathrm{kg}$ ); a dose-dependent 

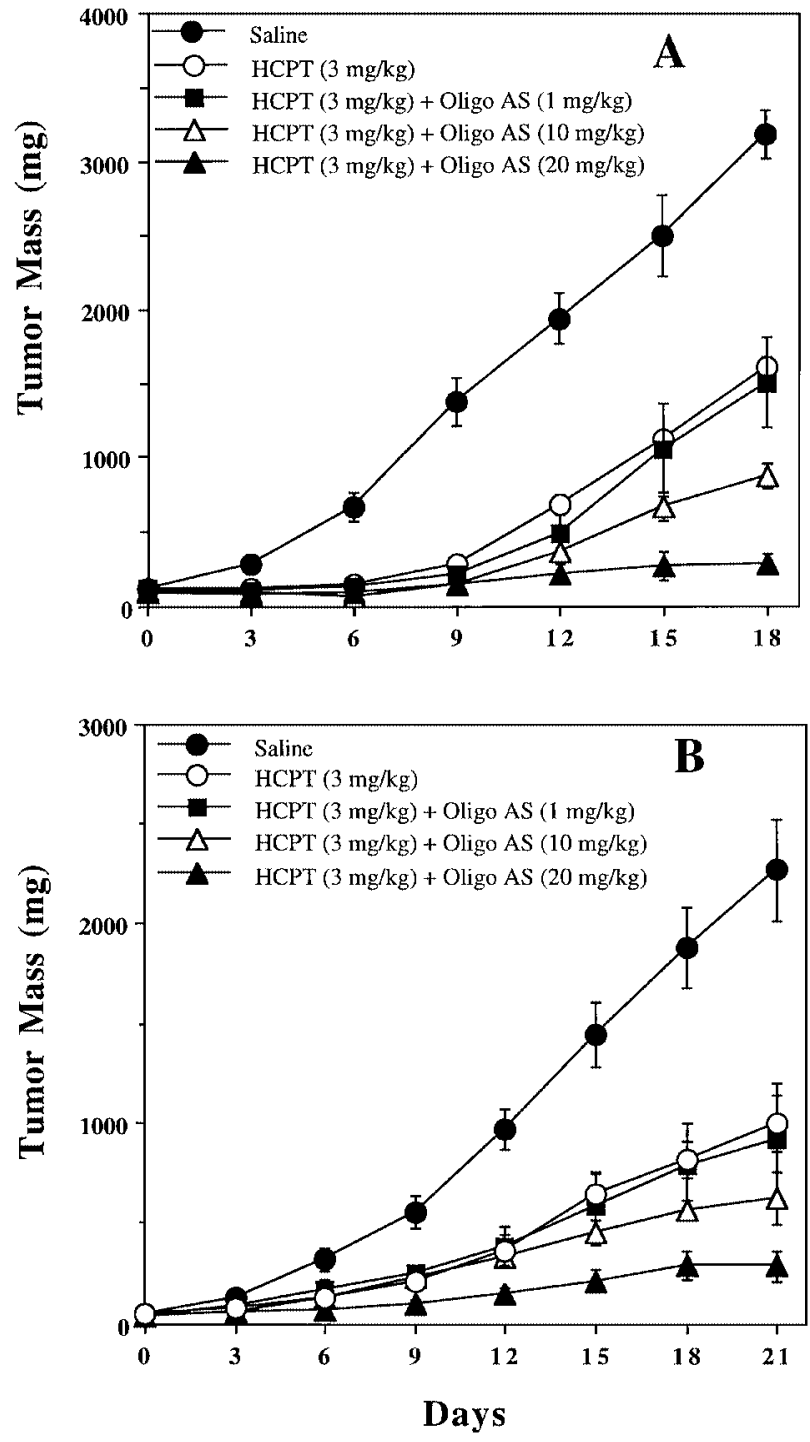

Fig. 5. Dose-dependent effects of Oligo AS on HCPT efficacy in LS174T (A) and DLD-1 (B) models. Doses for drugs alone or in combinations are Oligo AS, 1, 10, and 20

$\mathrm{mg} / \mathrm{kg} /$ day 5 days/week for 2 weeks; and HCPT, $3 \mathrm{mg} / \mathrm{kg} /$ day for the first week and $3 \mathrm{mg} / \mathrm{kg}$ every other day for remaining treatment period.

response was observed (Fig. 7A). At $1 \mathrm{mg} / \mathrm{kg} /$ day, Oligo AS showed minimal effects on tumor growth. The mismatched control Oligo ASM showed minimal effects at $20 \mathrm{mg} / \mathrm{kg} /$ day (Fig. 7B, Table 3). Following treatment with HCPT $(3 \mathrm{mg} / \mathrm{kg} /$ day for the first week and $3 \mathrm{mg} / \mathrm{kg}$ every other day for remaining treatment period), tumor growth was inhibited by approximately $51 \%$ at the end of the experiment (day 21) (Fig. 7B and Table 3). Following combined treatment with Oligo AS and HCPT, significant additive or synergistic effects were observed (Fig. 7B and Table 3). At the end of the experiment, the mean tumor size of the animals treated with HCPT and Oligo AS was $20 \%$ of that of the control animals treated with saline, whereas the mean tumor sizes for animals treated with Oligo AS or HCPT alone were $36.8 \%$ and $51.0 \%$ of that of the controls, respectively (Table 3). Similar significantly additive or synergistic effects were observed following combined treatment with Oligo AS and 5-FU (Fig. 7C and Table 3). At the end of the experiment, the mean tumor size of the animals treated with 5-FU and Oligo AS was $23.1 \%$ of that of the control animals treated with saline, whereas the mean tumor sizes for animals treated with Oligo AS or HCPT alone were $36.8 \%$ and $44 \%$ of that of the controls, respectively (Table 3). The mismatched control Oligo ASM showed no substantial effects on HCPT- or 5-FUassociated tumor growth inhibition (Fig. 7B and 7C, Table 3), further confirming the specificity of Oligo AS as an antisense agent.

Xenograft Pathology Tumors from control mice (saline or Oligo ASM) were composed of very tightly packed cells with round to oval, open-faced nuclei and modest amounts of cytoplasm, forming sheets, and cords of cells separated by very thin zones of fibrous connective tissue. Although the tumor masses from mice treated with chemotherapeutic agents HCPT and 5-FU alone or in combination with Oligo AS were significantly smaller than control tumors, they were histologically similar to the control tumors from mice. Tumors from mice treated with Oligo AS were histologically similar to control tumors except for modest increases in connective tissue with necrotic changes in tumor tissues.

Host Toxicity No significant increase in host toxicity, in terms of body weight gain/loss and survival rates, was observed with combination treatment of Oligo AS and HCPT or 5-FU (Table 4). Of note, in the HCPT and Oligo ASM combination, survival rates were lower than the controls, which, however, is not appreciably different from that of the control groups in the study of LS174T model (Table 2), suggesting that the host toxicity observed in the groups treated with the combination protocol (HCPT plus Oligo ASM or AS) be associated with HCPT (Tables 2 and 4).

In vivo Inhibition of MDM2 Expression Western blot analyses of pooled DLD-1 xenograft tissues indicated that Oligo AS specifically inhibited MDM2 expression in a dose-dependent manner in vivo (Fig. 4 B). The control Oligo ASM had no effect on the protein levels, further demonstrating the specificity of Oligo AS. No changes in p53 levels were observed, indicating that in vivo antitumor activity of Oligo AS is independent of p53.

Dose-dependent Effects of Oligo AS on Chemotherapeutic Effects of HCPT in DLD-1 Model To confirm these results, in vivo synergistic effects between HCPT and Oligo AS were further determined in DLD-1 model, in a separate study using three different doses of 


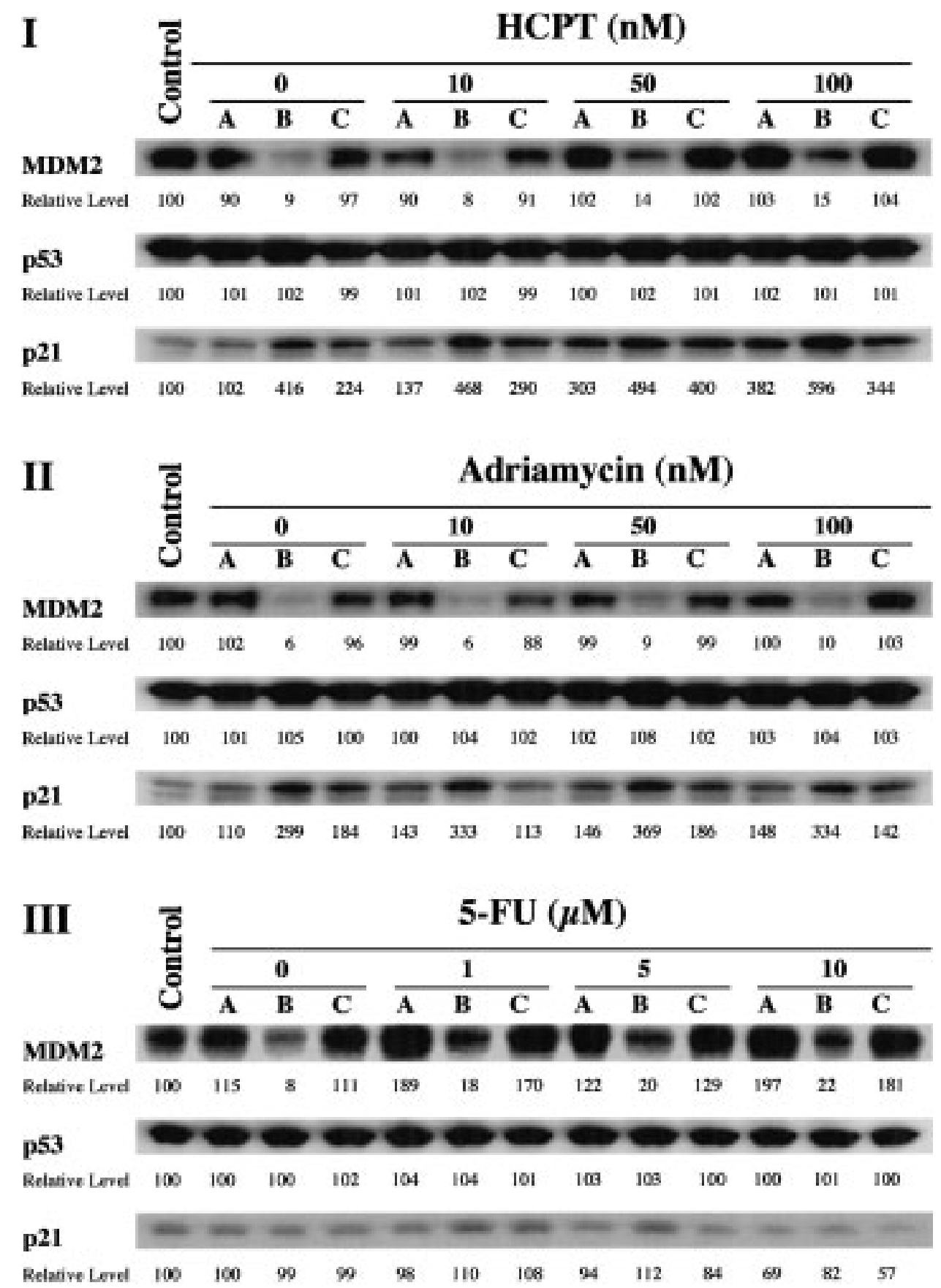

Fig. 6. Effects of combination treatment of Anti-MDM2 Oligo AS and the cancer chemotherapeutic agents on MDM2, p53, and p21 protein levels in DLD-1 cells in culture. Cells were incubated with $200 \mathrm{nM}$ Oligo AS or ASM in the presence of lipofectin for $24 \mathrm{hr}$, followed by addition of various concentrations of HCPT (panel I), adriamycin (panel II), or 5-FU (panel III) and incubation for additional $24 \mathrm{hr}$. At various concentrations, the effects on MDM2, p53, and p2 l levels were evaluated following treatment with cytotoxic agents alone (lanes A) or pre-treatment with Oligo AS (lanes B) or Oligo ASM (lanes C). Relative levels of each protein were expressed as percentage of control (no treatment), normalized by corresponding $\beta$-actin level.

Oligo AS (1, 10, $20 \mathrm{mg} / \mathrm{kg} /$ day, 5 days/week for 2 weeks). As illustrated in Figure 5B, at the $1 \mathrm{mg} / \mathrm{kg}$ level, Oligo AS showed no effect on HCPT therapeutic efficacy. At the 10 and $20 \mathrm{mg} / \mathrm{kg}$ levels, Oligo AS significantly increased HCPT efficacy in a dosedependent manner.

\section{Discussion}

The MDM2 oncogene has been suggested as a novel target for cancer therapy, especially the p53-MDM2 interaction $(6-8,32-39,46,47)$. The rationale for this is based on the following observations: a) MDM2 amplification and overexpression occur in many types of 

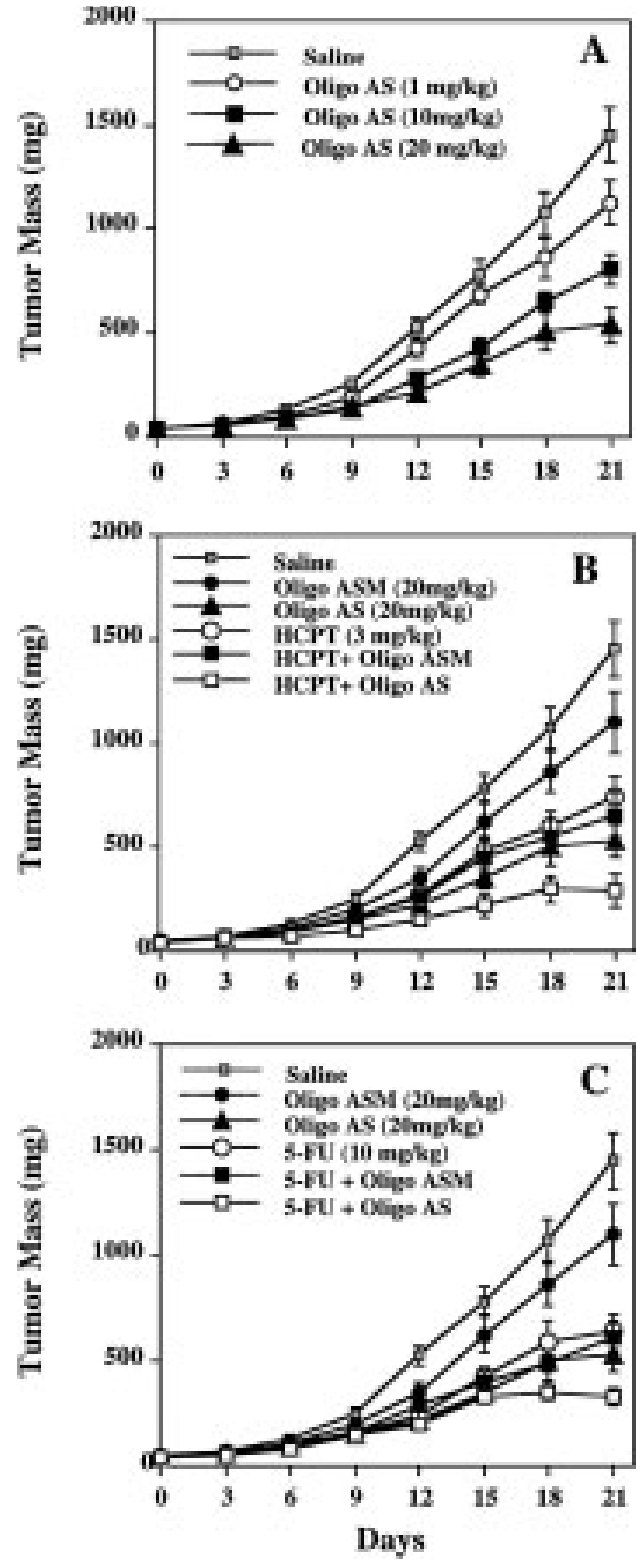

Fig. 7. In vivo antitumor activities of Oligo AS administered alone or in combination with HCPT and 5-Fu in mice bearing human colon cancer DLD-1 xenografts. Doses for Oligo AS alone were 1, 10, and $20 \mathrm{mg} / \mathrm{kg} /$ day (panel A). Doses in combination therapy were the same as that with LS174T model. In a dose-dependent manner, Oligo AS inhibited DLD-1 tumor growth (panel A). Additive or synergistic therapeutic effects were observed in combination therapy with Oligo AS and HCPT (panel B) or 5-FU (panel C). The therapeutic effectiveness for each treatment is summarized in Table 3. The host toxicity (survival rate) is summarized in Table 4.

human cancers and the MDM2 levels correlate with poor prognosis in some cancers; b) p53, which is negatively regulated by MDM2, plays a major role in tumor growth; c) p53-mediated growth arrest and/or apoptosis have been suggested to be major mechanisms for currently used cancer therapy such as DNAdamaging chemotherapeutics and radiation therapy; d) loss of p53 function and/or overexpression of
MDM2 is believed to correlate with tumor resistance to conventional therapy; and e) MDM2 has displayed both p53-dependent and p53-independent activities in connection with its tumorigenic properties. In the past few years, several strategies have been used to test the hypothesis that, by disrupting p53-MDM2 interaction, the negative regulation of p53 by MDM2 is diminished and the cellular functional p53 level is increased, particularly following DNAdamaging treatment, resulting in tumor growth arrest and/or apoptosis that leads to better therapeutic responses. These approaches include the use of polypeptides (33), antibodies $(34,35)$, and antisense oligonucleotides (37-39).

Recently, we identified an anti-MDM2 antisense PS-oligo that effectively inhibits MDM2 expression in tumor cells containing MDM2 gene amplifications (37). Anti-human-MDM2 antisense PS-oligos were initially screened in two cell lines, JAR (choriocarcinoma) and SJSA (osteosarcoma), which contain wild-type p53, amplified MDM2 genes, and overexpression of MDM2 oncoprotein. Of nine PSoligos screened, Oligo AS5 (5'-GATCACTCCCACCTTCAAGG-3'), which can hybridize to a position $\sim 360$ bp downstream of the translation start codon, reproducibly decreased MDM2 protein levels in both cell lines by 3- to 5-fold at concentrations of 100-400 nM in the presence of lipofectin (37). Oligo AS5 also induced RNase $\mathrm{H}$ cleavage of the target MDM2 mRNA, resulting in truncation and degradation of the target (37). Following AS5 treatment, the p53 protein level was elevated and its activity was increased as evidenced by induction of p2 1 expression. JAR cells treated with AS5 showed a substantial increase in the levels of apoptosis (37). AS5 did not cause visible apoptosis in the H1299 cells that lack p53 (37). These results suggest that apoptosis induced by AS5 is due to activation of $\mathrm{p} 53$ following MDM2 inhibition by the oligo.

After publishing the above encouraging observations with Oligo AS5 (37), we continued the screening project with the primary goals being to a) obtain new oligos with better in vivo stability, b) determine the effects of anti-MDM2 oligos on human tumor cells with varying status of p53 and/or MDM2 expression, and c) identify candidate cell lines that can be used in future in vivo studies. In tested cell lines, PS-oligo AS5-2 (5'-TGACACCTGTTCTCACTCAC-3') had the highest activity and were used in further studies. Among 26 cell lines (16 types of human cancers) tested, Oligo AS5-2 significantly activated p53 in all cells with low levels of wild-type p53, even in those with very low levels of MDM2 (38). AS5-2 has no effect on p53 levels in cells with null p53, H1299, and SK-N-MC, or those with mutant p53 (38). Based on the above screening, a modified analog of AS5-2 with advanced antisense chemistry, Oligo AS, was designed and evaluated in subsequent studies. In cell lines that contain wild-type p53 and amplified 
Table 3. Therapeutic effectiveness of anti-MDM2 oligonucleotide administered alone or in combination with cytotoxic agents in mice bearing human colon cancer DLD-1 xenografts

\begin{tabular}{|c|c|c|c|c|c|c|}
\hline \multirow[b]{2}{*}{ Day } & & \multirow{2}{*}{$\begin{array}{c}\text { No Oligo } \\
{[1]} \\
(\% \mathrm{~T}: \mathrm{C})\end{array}$} & \multicolumn{2}{|c|}{$+\mathbf{A S M}$} & \multicolumn{2}{|c|}{ +Anti-MDM2 AS } \\
\hline & & & $\begin{array}{c}{[2]} \\
(\% \mathrm{~T}: \mathrm{C})\end{array}$ & $\begin{array}{c}\text { Ratio (\%) } \\
([2] /[1])\end{array}$ & $\begin{array}{c}{[3]} \\
(\% \mathrm{~T}: \mathrm{C})\end{array}$ & $\begin{array}{c}\text { Ratio (\%) } \\
([3] /[1])\end{array}$ \\
\hline 3 & $\begin{array}{l}\text { Oligo alone } \\
\text { HCPT } \\
5-F U\end{array}$ & $\begin{array}{r}100 \\
88 \\
79\end{array}$ & $\begin{array}{l}82 \\
93 \\
85\end{array}$ & $\begin{array}{r}82 \\
106 \\
108\end{array}$ & $\begin{array}{l}77 \\
80 \\
74\end{array}$ & $\begin{array}{l}77 \\
91 \\
93\end{array}$ \\
\hline 6 & $\begin{array}{l}\text { Oligo alone } \\
\text { HCPT } \\
5-F U\end{array}$ & $\begin{array}{r}100 \\
74 \\
76\end{array}$ & $\begin{array}{l}88 \\
69 \\
86\end{array}$ & $\begin{array}{r}88 \\
93 \\
113\end{array}$ & $\begin{array}{l}72 \\
56 \\
65\end{array}$ & $\begin{array}{l}72 \\
76 \\
85\end{array}$ \\
\hline 9 & $\begin{array}{l}\text { Oligo alone } \\
\text { HCPT } \\
5-F U\end{array}$ & $\begin{array}{r}100 \\
62 \\
61\end{array}$ & $\begin{array}{l}79 \\
62 \\
65\end{array}$ & $\begin{array}{r}70 \\
99 \\
106\end{array}$ & $\begin{array}{l}59 \\
41 \\
58\end{array}$ & $\begin{array}{l}59 \\
65 \\
95\end{array}$ \\
\hline 12 & $\begin{array}{l}\text { Oligo alone } \\
\text { HCPT } \\
5-\mathrm{FU}\end{array}$ & $\begin{array}{r}100 \\
51 \\
46\end{array}$ & $\begin{array}{l}66 \\
49 \\
54\end{array}$ & $\begin{array}{r}66 \\
96 \\
118\end{array}$ & $\begin{array}{l}41 \\
28 \\
38\end{array}$ & $\begin{array}{l}41 \\
54 \\
83\end{array}$ \\
\hline 15 & $\begin{array}{l}\text { Oligo alone } \\
\text { HCPT } \\
5-\mathrm{FU}\end{array}$ & $\begin{array}{r}100 \\
61 \\
54\end{array}$ & $\begin{array}{l}79 \\
58 \\
51\end{array}$ & $\begin{array}{l}79 \\
95 \\
93\end{array}$ & $\begin{array}{l}44 \\
28 \\
42\end{array}$ & $\begin{array}{l}44 \\
45 \\
78\end{array}$ \\
\hline 18 & $\begin{array}{l}\text { Oligo alone } \\
\text { HCPT } \\
5-\mathrm{FU}\end{array}$ & $\begin{array}{r}100 \\
56 \\
56\end{array}$ & $\begin{array}{l}81 \\
52 \\
46\end{array}$ & $\begin{array}{l}81 \\
92 \\
83\end{array}$ & $\begin{array}{l}47 \\
27 \\
33\end{array}$ & $\begin{array}{l}47 \\
49 \\
60\end{array}$ \\
\hline 21 & $\begin{array}{l}\text { Oligo alone } \\
\text { HCPT } \\
5-F U\end{array}$ & $\begin{array}{r}100 \\
51 \\
44\end{array}$ & $\begin{array}{l}76 \\
45 \\
43\end{array}$ & $\begin{array}{l}76 \\
88 \\
97\end{array}$ & $\begin{array}{l}37 \\
20 \\
23\end{array}$ & $\begin{array}{l}37 \\
39 \\
53\end{array}$ \\
\hline
\end{tabular}

MDM2 gene, SJSA and JAR, Oligo AS specifically inhibited MDM2 expression and p53 levels were elevated accordingly (39). This oligo has been shown to be active in in vitro and in vivo breast cancer models (48).

The purpose of the present study was to investigate further the role of MDM2 in human colon cancer using in vitro and in vivo models that contain wild-type p53 (LS174T) or mutant p53 (DLD-1) but with MDM2 expression. We demonstrated at least five significant results. First, the novel anti-MDM2 mixed-backbone oligonucleotide Oligo AS specifically inhibited MDM2 expression in both LS174T and DLD-1 cells, with dose-dependent inhibitory effects on cell growth, regardless of p53 status. Second, in a dose-dependent manner, the in vivo antitumor effects of Oligo AS were observed in LS174T and DLD-1 tumor models in nude mice, following sequence-specific, dose-dependent inhibition of MDM2 expression in vivo. Third, after combination therapy with Oligo AS and conventional cancer chemotherapeutic agents HCPT and 5-FU, in vivo synergistic or additive therapeutic effects were found in both LS174T and DLD-1 models. Fourth, in LS 174T cells, combination treatment with Oligo AS and cancer chemotherapeutic agents HCPT, adriamycin and 5-FU significantly elevated chemotherapeutic agent-induced p53 and p21 levels, resulting from inhibition of chemotherapeutic agent-induced MDM2 expression, indicating that the in vivo synergistic effects between Oligo AS and conventional chemotherapeutic agents are associated with a p53dependent pathway in cancers containing wild-type p53 expression. Finally, in DLD- 1 cells, combination treatment with Oligo AS and the cancer chemotherapeutic agents HCPT, adriamycin, and 5-FU had no effect on the mutant p53 levels. Oligo AS specifically inhibited the chemotherapeutic agent-induced MDM2 expression and increased p2l levels, indicating that the in vivo synergistic or additive effects between Oligo AS and the chemotherapeutic agents are independent of p53 but associated with MDM2 and possibly with p2l.

In general, human cancer cell lines or tumor tissues with MDM2 gene amplifications or overexpression often have wild-type p53 (4-9), presumably inactivated by MDM2. Several studies have now shown that overexpression of MDM2 is associated with poor prognosis in human malignancies, including osteosarcoma (14), soft tissue sarcoma $(15-17,49)$, breast cancer (18), ovarian cancer (19), cervical cancer (20), oral squamous cell carcinoma $(21,22)$, brain tumor $(23,50)$, esophageal cancer $(24)$, colorectal carcinoma (25), bladder cancer (26-28, 51), urothelial carcinoma (29), leukemia (30), and large B-cell lymphoma (31). These studies suggest 


\begin{tabular}{|c|c|c|c|c|}
\hline $\begin{array}{l}\text { Day } \\
\text { AS }\end{array}$ & & $\begin{array}{c}\text { No Oligo } \\
(\%)\end{array}$ & $+\underset{(\%)}{\operatorname{ASM}}$ & $\begin{array}{c}\text { Anti-MDM2 } \\
(\%)\end{array}$ \\
\hline 3 & $\begin{array}{l}\text { Oligo alone } \\
\text { HCPT } \\
5-\mathrm{FU}\end{array}$ & $\begin{array}{l}100 \\
100 \\
100\end{array}$ & $\begin{array}{l}100 \\
100 \\
100\end{array}$ & $\begin{array}{l}100 \\
100 \\
100\end{array}$ \\
\hline 6 & $\begin{array}{l}\text { Oligo alone } \\
\text { HCPT } \\
5-\mathrm{FU}\end{array}$ & $\begin{array}{l}100 \\
100 \\
100\end{array}$ & $\begin{array}{l}100 \\
100 \\
100\end{array}$ & $\begin{array}{r}100 \\
83 \\
100\end{array}$ \\
\hline 9 & $\begin{array}{l}\text { Oligo alone } \\
\text { HCPT } \\
5 \text {-FU }\end{array}$ & $\begin{array}{l}100 \\
100 \\
100\end{array}$ & $\begin{array}{r}100 \\
67 \\
100\end{array}$ & $\begin{array}{r}100 \\
83 \\
100\end{array}$ \\
\hline 12 & $\begin{array}{l}\text { Oligo alone } \\
\text { HCPT } \\
5-\mathrm{FU}\end{array}$ & $\begin{array}{l}100 \\
100 \\
100\end{array}$ & $\begin{array}{r}100 \\
50 \\
100\end{array}$ & $\begin{array}{r}100 \\
83 \\
100\end{array}$ \\
\hline 15 & $\begin{array}{l}\text { Oligo alone } \\
\text { HCPT } \\
5 \text {-FU }\end{array}$ & $\begin{array}{l}100 \\
100 \\
100\end{array}$ & $\begin{array}{r}100 \\
50 \\
100\end{array}$ & $\begin{array}{r}100 \\
83 \\
100\end{array}$ \\
\hline 18 & $\begin{array}{l}\text { Oligo alone } \\
\text { HCPT } \\
5-F U\end{array}$ & $\begin{array}{l}100 \\
100 \\
100\end{array}$ & $\begin{array}{r}100 \\
50 \\
100\end{array}$ & $\begin{array}{r}100 \\
83 \\
100\end{array}$ \\
\hline 21 & $\begin{array}{l}\text { Oligo alone } \\
\text { HCPT } \\
5-F U\end{array}$ & $\begin{array}{l}100 \\
100 \\
100\end{array}$ & $\begin{array}{r}67 \\
50 \\
100\end{array}$ & $\begin{array}{r}100 \\
83 \\
100\end{array}$ \\
\hline
\end{tabular}

that overexpression of MDM2 may be associated with inactivation of wild-type p53, and inhibiting MDM2 expression in these tumors may lead to re-activation of p53 and induction of cell growth arrest or apoptosis. Many cancer therapeutic agents exert their cytotoxic effects through activation of wild-type p53, and the restoration of wild-type p53 can increase the sensitivity of tumors to DNA-damaging agents (52). Restoration of wild-type p53 may also overcome the drug resistance of human cancers associated with p53 dysfunction (53). Activation of p53 by DNA damage such as cancer chemotherapy and radiation treatment may, however, be limited in cancers with MDM2 expression, especially those with MDM2 overexpression. Therefore, inactivation of the MDM2 negative feed-back loop may increase the magnitude of p53 activation following DNA damage, thus enhancing the therapeutic effectiveness of DNA-damaging drugs. In the present study, we provide experimental evidence supporting this hypothesis. In LS 174T cells that contain wild-type p53, the cancer chemotherapeutic agents HCPT, adriamycin, and 5-FU induced p53 levels, but this was limited owing to MDM2 overexpression. Following treatment with antisense anti-MDM2 Oligo AS, MDM2 expression was specifically inhibited, resulting in significantly increases in cytotoxic agent-induced p53 and p21 levels. These findings are consistent with the in vivo synergistic effects following combination treatment of Oligo AS and the cytotoxic agents HCPT or 5-FU. These results further confirm our earlier findings with cell lines that contain amplified MDM2 gene and overexpressed MDM2 protein (37-39). Therefore, we conclude that the MDM2-p53 interaction can serve as a novel drug target, even if MDM2 and/or p53 are expressed at basal levels.

In addition to its interaction with p53, MDM2 binds to and interacts with other cellular proteins such as the pRB (54), E2Fl (55), p300 (56), ARF (57-59), p73 (60), Numb (61), and ribosomal protein L5 (62), and RNA (63), and regulates the MyoD transcription factor (64). The biological consequences of these activities are not fully understood, but may be associated with transforming properties of MDM2 that may be p53 independent (6-9). MDM2 gene products include several forms of polypeptide, representing alternatively spliced MDM2 variants (65). Various alternatively spliced MDM2 polypeptides are present in several human tumors (66-68). Of the five forms of MDM2 analogs, only one retains p53binding capacity. However, cDNAs coding for all five forms of alternatively spliced MDM2 independently transform NIH3T3 cells, indicating that these MDM2 transcripts have the p53-independent transforming ability $(66,67)$. The effects of MDM2 overexpression on mammary tumorigenicity are seen in p53-null mice (69), indicating that MDM2 can cause transformation and tumor formation via a p53-independent mechanism. Furthermore, overexpression of MDM2 is associated with resistance to the antiproliferative effects of transforming growth factor $\beta$ (TGF- $\beta$ ), which is p53 independent (70).

In the present study, we provide direct evidence supporting the possibility of p53-independent activity of MDM2. In DLD-1 cells that contain mutant p53, Oligo AS and the cancer chemotherapeutic agents HCPT, adriamycin, and 5-FU had no effect on the mutant p53 levels. These cytotoxic agents, however, induced MDM2 levels and p21 levels. The mechanisms are not clear. Following treatment with Oligo AS, MDM2 expression was specifically inhibited, resulting in a significant increase in cytotoxic agent (HCPT and adriamycin)-induced p21 levels. More important, the in vivo antitumor activity of Oligo AS was observed in the DLD-1 model following administration alone or in combination with the cytotoxic agents HCPT or 5-FU, which is independent of p53 status.

Although the mechanisms responsible for increasing p21 levels following MDM2 inhibition were not determined in the present study, the interaction between MDM2 and p2 1 is indicated. In human tumor cells treated with HCPT, up-regulation of p2 1 has been suggested to be both p53 dependent and p53 independent (45). Further study should elucidate the potential interaction between MDM2 and p2 1 and its role in tumor transformation and growth. 
One of the advantages of using antisense oligonucleotides or MDM2-specific antibodies is that these agents may exert their effects in all MDM2expressing tumors regardless of p53 status. This is important because the p53-independent activity of MDM2 may play a role in MDM2 tumorigenicity. Inhibition of MDM2 expression will ultimately prevent the interaction of MDM2 and other cellular proteins.

One potential drawback is that these agents may have similar effects on normal host tissues, resulting in activation of endogenous p53 (71). The tolerance of increased p53 levels in normal tissues will be the key for the success of approaches aimed at eliminating MDM2 from cells. The activation of $\mathrm{p} 53$ in normal tissues following DNA-damaging treatment and the resultant cell growth arrest and apoptosis are believed to be associated with side toxicities of conventional therapy. A recent study demonstrated that inhibition of p53 function can in fact prevent host toxicity associated with DNA-damaging treatment (72). In the present study, no significant changes were observed in host toxicity following combination therapy with Oligo AS and cytotoxic agents in either tumor models. However, this does not rule out the possibility of increased host toxicity, especially through the p53-dependent pathway; the antisense oligonucleotide used is human-MDM2-specific and, therefore, may have little effect on mouse normal tissues. Further study examining the potential host toxicity following treatment of anti-mouse-MDM2 oligonucleotides is underway.

In conclusion, we demonstrated that the selected specific anti-human-MDM2 mixed-backbone oligonucleotide has significant anti-tumor activity in vitro and in vivo, regardless of p53 status. These results suggest that MDM2 have a role in tumor growth through both p53-dependent and p53-independent mechanisms. We speculate that MDM2 inhibitors such as antisense anti-MDM2 oligonucleotides have a broad spectrum of antitumor activities in human cancers regardless of p53 status. Therefore, this study should provide a basis for future development of anti-MDM2 antisense oligonucleotides as cancer therapeutic agents used alone or in combination with conventional chemotherapeutics (73).

\section{Acknowledgments}

This study was supported by National Institute of Health grant R01 CA 80698 (to R.Z.). We thank Dr. J. Chen for providing anti-MDM2 antibodies, L. P. Le, J. Sutton, M. Shackelford, and J. Hosmer for their excellent technical assistance.

\section{References}

1. Prives C, Hall PA. (1999) The p53 pathway. J. Pathol. 187: 112-126.

2. Fakharzadeh SS, Trusko SP, George DL. (1991) Tumorigenic potential associated with enhanced expression of a gene that is amplified in a mouse tumor cell line. EMBO J. 10: 1565-1569.
3. Piette J, Neel H, Marechal V. (1997) Mdm2: keeping p53 under control. Oncogene 15: 1001-1010.

4. Momand J, Zambetti GP. (1997) Mdm-2: “big brother" of p53. J. Cell. Biochem. 64: 343-352.

5. Lozano G, Montes de Oca Luna R. (1998) MDM2 function. Biochim. Biophys. Acta 1377: M55-M59.

6. Juven-Gershon T, Oren M. (1999) Mdm2: the ups and downs. Mol. Med. 5: 71-83.

7. Freedman DA, Wu L, Levine AJ. (1999) Functions of the MDM2 oncoprotein. Cell Mol. Life Sci. 55: 96-107.

8. Freedman DA, Levine AJ. (1999) Regulation of $\mathrm{p} 53$ protein by MDM2 oncoprotein-Thirty eighth G.H.A. Clowes memorial award lecture. Cancer Res. 59: 1-7.

9. Momand J, Jung D, Wilczynski S, Niland J. (1998) The MDM2 gene amplification database. Nucleic Acids Res. 26: 3453-3459.

10. Bueso-Ramos CE, Yang Y, deLeon E, McCown P, Stass, SA, Albitar M. (1993) The human MDM-2 oncogene is overexpressed in leukemias. Blood 82: 2617-2623.

11. Watanabe T, Hotta T, Ichikawa A, et al. (1994) The MDM2 oncogene overexpression in chronic lymphocytic leukemia and low-grade lymphoma of B-cell origin. Blood 84: 3158-3165.

12. Landers JE, Haines DS, Strauss JF, George DL. (1994) Enhanced translation: a novel mechanism of $\mathrm{mdm} 2$ oncogene overexpression identified in human tumor cells. Oncogene 9: 2745-2750.

13. Landers JE, Cassel SL, George DL. (1997) Translational enhancement of mdm2 oncogene expression in human tumor cells containing a stabilized wild-type p53 protein. Cancer Res. 57: 3562-3568.

14. Lonardo F, Ueda T, Huvos AG, Healey J, Ladanyi M. (1997) P53 and MDM2 alterations in osteosarcomas. Cancer 79: 1541-1547.

15. Wurl P, Meye A, Berger D, et al. (1997) Prognostic relevance of C-terminal mdm2 detection is enhanced by p 53 positivity in soft tissue sarcomas. Diagnostic Mol. Pathol. 6: 249-254.

16. Stefanou DG, Nonni AV, Agnantis NJ, Athanassiadou SE, Briassoulis E, Pavlidis N. (1998) P53/MDM-2 immunohistochemical expression correlated with proliferative activity in different subtypes of human sarcomas: a ten-year follow-up study. Anticancer Res. 18: 4673-4682.

17. Yokoyama R, Schneider-Stock R, Radig K, Wex T, Roessner A. (1998) Clinicopathologic implications of MDM2, p53 and $\mathrm{K}$-ras gene alterations in osteosarcomas: MDM2 amplification and p53 mutations found in progressive tumors. Pathol. Res. Pract. 194: 615-621.

18. Jiang M, Shao Z-M, Wu J, et al. (1997) P21/wafl/cipl and mdm-2 expression in breast carcinoma patients as related to prognosis. Int. J. Cancer (Pred. Oncol.) 74: 529-534.

19. Tanner B, Hengstler JG, Laubscher S, et al. (1997) Mdm2 mRNA expression is associated with survival in ovarian cancer. Int. J. Cancer (Pred. Oncol.) 74: 438-442.

20. Dellas A, Schultheiss E, Almendral AC, et al. (1997) Altered expression of $\mathrm{mdm} 2$ and its association with $\mathrm{p} 53$ protein status, tumor-cell-proliferation rate and prognosis in cervical neoplasia. Int. J. Cancer (Pred. Oncol.) 74: 421-425.

21. Girod SC, Pfeiffer P, Ries J, Pape H-D. (1998) Proliferative activity and loss of function of tumor suppressor genes as biomarkers in diagnosis and prognosis of benign and preneoplastic oral lesions and oral squamous cell carcinoma. Br. J. Oral Maxillofacial Surg. 36: 252-260.

22. Agrawal S, Mathur M, Srivastava A, Ealhan R. (1999) MDM2/p53 co-expression in oral premalignant and malignant lesions: potential prognostic implication. Oral Oncol. 35: 209-2 16 .

23. Ehrmann J, Kolar Z, Vojtesek B, Kala M, Komenda S, Oulton A. (1997) Prognostic factors in astrocytomas: relationship of p53, MDM-2, Bcl-2 and PCNA immunohistochemical expression to tumor grade and overall patient survival. Neoplasma 44: 299-304.

24. Shimada Y, Imamura M, Shibagaki I, et al. (1997) Genetic alterations in patients with esophageal cancer with short- and long-term survival rates after curative esophagectomy. Ann. Surg. 226: 162-168. 
25. Valassiadou K, Stenfanaki K, Tzardi M, et al. (1997) Immunohistochemical expression of $\mathrm{p} 53, \mathrm{bcl} 2, \mathrm{mdm} 2$ and waf 1/p21 proteins in colorectal adenocarcinomas. Anticancer Res. 17: 2571-2576.

26. Korkolopoulou P, Christodoulou P, Kapralos P, et al. (1997) The role of p53, MDM2 and c-erb B-2 oncoproteins, epidermal growth factor receptor and proliferation markers in the prognosis of urinary bladder cancer. Pathol. Res. Pract. 193: $767-775$.

27. Osman I, Scher H, Zhang Z-F, et al. (1997) Alterations affecting the p53 control pathway in Bilharzial-related bladder cancer. Clin. Cancer Res. 3: 531-536.

28. Shiina H, Igawa M, Shigeno K, et al. (1999) Clinical significance of mdm2 and p53 expression in bladder cancer. A comparison with cell proliferation and apoptosis. Oncology 56: 239-247.

29. Ozdemir E, Kakehi Y, Okuno H, Habuchi T, Okada Y, Yoshida O. (1997) Strong correlation of basement membrane degradation with p53 inactivation and/or MDM2 overexpression in superficial urithelial carcinomas. J. Urol. 158: 206-211.

30. Marks DI, Kurz BW, Link MP, et al. (1997) Altered expression of p53 and mdm-2 proteins at diagnosis is associated with early treatment failure in childhood acute lymphoblastic leukemia. J. Clin. Oncol. 15: 1158-1162.

31. Sanchez E, Chacon I, Plaza MM, et al. (1998) Clinical outcome in diffuse large B-cell lymphoma is dependent on the relationship between different cell-cycle regulator proteins. $J$. Clin. Oncol. 16: 1931-1939.

32. Prives C. (1998) Signaling to p53: breaking the MDM2-p53 circuit. Cell 95: 5-8.

33. Bottger A, Bottger V, Sparks A, Liu WL, Howard SF, Lane DP. (1997) Design of a synthetic Mdm2-binding mini protein that activates the p53 response in vivo. Curr. Biol. 7: 860-869.

34. Midgley CA, Lane DP. (1997) P53 protein stability in tumor cells is not determined by mutation but is dependent on Mdm2 binding. Oncogene 15: 1179-1189.

35. Bottger A, Bottger A, Garcia EC, et al. (1997) Molecular characterization of the hdm2-p53 interaction. J. Mol. Biol. 269: 744-756.

36. Blattner C, Sparks A, Lane D. (1999) Transcription factor E2F-1 is upregulated in response to DNA damage in a manner analogous to that of p53. Mol. Cell. Biol.19: 3704-3713.

37. Chen L, Agrawal S, Zhou W, Zhang R, Chen J. (1998) Synergistic activation of $\mathrm{p} 53$ by inhibition of MDM2 expression and DNA damage. Proc. Natl. Acad. Sci. U.S.A. 95: 195-200.

38. Chen L, Agrawal S, Zhou W, Zhang R, Chen J. (1999) Ubiquitous induction of p53 in tumor cells by antisense inhibition of MDM2 expression. Mol. Med. 5: 21-34.

39. Wang H, Oliver P, Zeng X, et al. (1999) MDM2 oncogene as a target for cancer therapy: an antisense approach. Int. J. Oncol. 15: 653-660.

40. Mandel JS. (1996) Screening for colon and rectal cancer. Cancer Cont. 3: 170-177.

41. Agrawal S, Jiang Z, Zhao Q, et al. (1997) Mixed-backbone oligonucleotides as second generation antisense oligonucleotides: In vitro and in vivo studies. Proc. Natl. Acad. Sci. U.S.A. 94: 2620-2625.

42. Zhang R, Li Y, Cai Q, Liu T, Sun H, Chambless B.(1998) Preclinical pharmacology of the natural product anticancer agent 10-hydroxycamptothecin, an inhibitor of topoisomerase I. Cancer Chemother. Pharm. 41: 257-267.

43. Cai Q, Lindsey JR, Zhang R. (1997) Regression of human colon cancer xenografts in SCID mice following oral administration of water-insoluble camptothecins, natural product topoisomerase I inhibitors. Int. J. Oncol. 10: 953960.

44. Wang H, Cai Q, Zeng X, Yu D, Agrawal S, Zhang R. (1999) Anti-tumor activity and pharmacokinetics of a mixed-backbone antisense oligonucleotide targeted to RI $\alpha$ subunit of protein kinase A after oral administration. Proc. Natl. Acad. Sci. U.S.A. 96: 13989-13994.
45. Liu W, Zhang R. (1998) Upregulation of $\mathrm{p} 21 /{ }^{\mathrm{WAF} 1 / \mathrm{CIP} 1}$ in human breast cancer cell lines MCF-7 and MDA-MB-468 undergoing apoptosis induced by natural product anticancer, agents 10-hydroxycamptothecin and camptothecin through p53-dependent and independent pathways. Int. J. Oncol. 12: 793-804.

46. Freedman DA, Levine AJ. (1998) Nuclear export is required for degradation of endogenous p 53 by MDM2 and human papillomavirus E6. Mol. Cell. Biol. 18: 7288-7293.

47. Zhang R, Wang H. (2000) MDM2 oncogene as a novel target for human cancer therapy. Curr. Pharm. Design 6: 393-416.

48. Wang H, Nan L, Yu D, Agrawal S, Zhang R. (2001) Antisense anti-MDM2 oligonucleotides as a novel therapeutic approach to human breast cancer: in vitro and in vivo activities and mechanisms. Clin. Cancer Res. 7: 3613-3624.

49. Wurl P, Meye A, Schmidt H, et al. (1998) High prognostic significance of $\mathrm{mdm} 2 / \mathrm{p} 53$ co-overexpression in soft tissue sarcomas of the extremities. Oncogene 16: 1183-1185.

50. Burton EC, Lamborn KR, Forsyth P, et al. (2002) Aberrant p53, MDM2, and proliferation differ in glioblastomas from long-term compared with typical survivors. Clin. Cancer Res. 8: $180-187$.

51. Lu M-L, Wikman F, Orntoft TF, et al. (2002) Impact of alterations affecting the $\mathrm{p} 53$ pathway in bladder cancer on clinical outcome, assessed by conventional and array-based methods. Clin. Cancer Res. 8: 171-179.

52. Dorigo O, Turla ST, Lebedeva S, Gjerset RA. (1998) Sensitization of rat glioblastoma multiforme to cisplatin in vivo following restoration of wild-type 533 function. J. Neurosurg. 88: 535-540.

53. Seth P, Katayose D, Li Z, et al. (1997). A recombinant adenovirus expressing wild type p53 induces apotosis in drug resistant human breast cancers: a gene therapy approach for drug-resistant cancers. Cancer Gene Ther. 4: 383-390.

54. Xiao Z, Chen J, Levine AJ, et al. (1995) Interaction between the retinoblastoma protein and the oncoprotein MDM2. Nature 375: 694-698.

55. Martin K, Trouche D, Hagemeier C, Sorensen TS, La Thangue NB, Kouzarides T. (1995) Stimulation of E2F1/DP1 transcriptional activity by MDM2 oncoprotein. Nature 375: 691-694.

56. Thomas A, White E. (1998) Suppression of the p300-dependent mdm2 negative-feedback loop induces the p53 apoptotic function. Genes Dev. 12: 1975-1985.

57. Pomerantz J, Schreiber-Agus N, Liegeois NJ, et al. (1998) The Ink4a tumor suppressor gene product, p19ARF, interacts with MDM2 and neutralizes MDM2's inhibition of p53. Cell 92: 713-723.

58. Honda R, Yasuda H. (1999) Association of pl9 ARF with mdm2 inhibits ubiquitin ligase activity of mdm2 for tumor suppressor p53. ЕMBO J. 18: 22-27.

59. Kamijo T, Weber JD, Zambetti G, Zindy F, Roussel MF, Sherr CJ. (1998) Functional and physical interactions of the ARF tumor suppressor with $\mathrm{p} 53$ and Mdm2. Proc. Natl. Acad. Sci. U.S.A. 95: 8292-8297.

60. Zeng X, Chen L, Jost CA, et al. (1999) Mdm2 suppresses p73 function without promoting p73 degradation. Mol. Cell. Biol. 19: 3257-3266.

61. Juven-Gershon T, Shifman O, Unger T, Elkeles A, Haupt Y, Oren M. (1998) The Mdm2 oncoprotein interacts with the cell fate regulator numb. Mol. Cell. Biol. 18: 3974-3982.

62. Marechal V, Elenbass B, Piette J, Nicolas JC, Levine AJ. (1994) The ribosomal L5 protein is associated with mdm2 and mdm-2-p53 complexes. Mol. Cell. Biol. 14: 74147420 .

63. Elenbaas B, Dobbelstein $M$, Roth J, Shenk T, Levine AJ. (1996) The MDM2 oncoprotein binds specifically to RNA through its RING finger domain. Mol. Med. 2: 439-45 1 .

64. Fiddler TA, Smith L, Tapscott SJ, Thayer MJ. (1996) Amplification of MDM2 inhibits MyoD-mediated myogenesis. Mol. Cell Biol. 16: 5048-5057.

65. Olson DC, Marechal V, Momand J, Chen J, Romocki C, Levine A. (1993) Identification and characterization of 
multiple mdm-2 proteins and mdm-2-p53 protein complexes. Oncogene 8: 2353-2360.

66. Sigalas I, Calvert AH, Anderson JJ, Neal DE, Lunec J. (1996) Alternatively spliced mdm2 transcripts with loss of p53 binding domain sequences: transforming ability and frequent detection in human cancer. Nat. Med. 2: 912-917.

67. Matsumoto R, Tada M, Nozaki M, Zhang C-L, Sawamura Y, Abe H. (1998) Short alternative splice transcripts of the mdm2 oncogene correlate to malignancy in human astrocytic neoplasms. Cancer Res. 58: 609-613.

68. Pinkas J, Naber SP, Butel JS, Medina D, Jerry DJ. (1999) Expression of MDM2 during mammary tumorigenesis. Int. J. Cancer 81: 292-298.

69. Lundgren K, Montes de Oca Luna R, Mcneill YB, et al. (1997) Targeted expression of MDM2 uncouples S phase from mitosis and inhibits mammary gland development independent of $\mathrm{p} 53$. Genes Dev. 11: 714-725.

70. Sun P, Dong P, Dai K, Hannon GJ, Beach D. (1998) p53independent role of MDM2 in TGF $\beta 1$ resistance. Science 282: 2270-2272.

71. Blaydes JP, Wynford-Thomas, D. (1998) The proliferation of normal human fibroblasts is dependent upon negative regulation of $\mathrm{p} 53$ function by $\mathrm{mdm} 2$. Oncogene 16: 33173322.

72. Komarov PG, Komarova EA, Kondratov RV, et al. (1999) A chemical inhibitor of p53 that protects mice from the side effects of cancer therapy. Science 285: 1733-1736.

73. Wang H, Prasad G, Buolamwini JK, Zhang R. (2001) Antisense anticancer oligonucleotide therapeutics. Curr. Cancer Drug Targets 1: 177-196. 